\title{
5 Research Square

\section{Mesoporous silica from Parangtritis beach sand templated by CTAB as a support of Mo Metal as a catalyst for hydrocracking of waste palm cooking oil into biofuel}

Gesha Desy Alisha ( $\nabla$ gesha.d.a@mail.ugm.ac.id)

Gadjah Mada University: Universitas Gadjah Mada

Wega Trisunaryanti

Universitas Gadjah Mada

Akhmad Syoufian

Universitas Gadjah Mada

\section{Research Article}

Keywords: Mesoporous Silica, Molybdenum, Wet Impregnation Method, Waste Palm cooking oil, Hydrocracking, Reusable Catalyst

Posted Date: August 18th, 2021

DOl: https://doi.org/10.21203/rs.3.rs-261236/v1

License: (c) (1) This work is licensed under a Creative Commons Attribution 4.0 International License.

Read Full License

Version of Record: A version of this preprint was published at Waste and Biomass Valorization on August 31st, 2021. See the published version at https://doi.org/10.1007/s12649-021-01559-y. 


\title{
Mesoporous silica from Parangtritis beach sand templated by CTAB as a support of Mo Metal as a catalyst for hydrocracking of waste palm cooking oil into biofuel \\ Gesha Desy Alisha $^{1}$, Wega Trisunaryanti ${ }^{*}$, Akhmad Syoufian ${ }^{1}$
}

\begin{abstract}
In this study, natural source Parangtritis beach sand was extracted into mesoporous silica (MS). Synthesis of mesoporous silica (MS) was carried out at sodium silicate: CTAB ratio of 1:0.5 (w/w). Monometallic catalyst was used to improve the performance of the catalyst. The monometallic used was Mo metal, which was synthesized using the wet impregnation method. Catalysts were characterized using FTIR, XRD, Surface Area Analyzer (SAA), SEM-EDX, and TEM. MS has pore diameters and surface area of $2.62 \mathrm{~nm}$ and $897.3 \mathrm{~m}^{2} / \mathrm{g}$. Mo/MS has pore diameters, surface area, and Mo metal concentration of $2.46 \mathrm{~nm}, 593 \mathrm{~m}^{2} / \mathrm{g}$, and $4.75 \%$. Catalytic activity and selectivity were evaluated in hydrocracking of waste palm cooking oil at 500, 550, and $600{ }^{\circ} \mathrm{C}$, and catalyst: waste palm cooking oil ratio of 1:100, 1:200, and 1:300. The best catalyst will be tested for reusability 3 times through the hydrocracking process. Mo/MS produces better liquid products and hydrocarbon compounds than MS. The results of the conversion of liquid products analyzed using GCMS. The yield of liquid products obtained in the hydrocracking of waste palm cooking oil using Mo/MS with the optimum temperature and the weight ratio of catalyst: feed at $550^{\circ} \mathrm{C}$ and 1: 300 was 66.99 wt.\% with consists of hydrocarbon compound as 62.79 wt.\%. The yield of liquid products obtained in the hydrocracking waste palm cooking oil using the used Mo/MS catalyst in the last run was 80.26 wt. \% with consist of hydrocarbon compound as 74.13 wt.\%.
\end{abstract}

\section{Graphic Abstract}

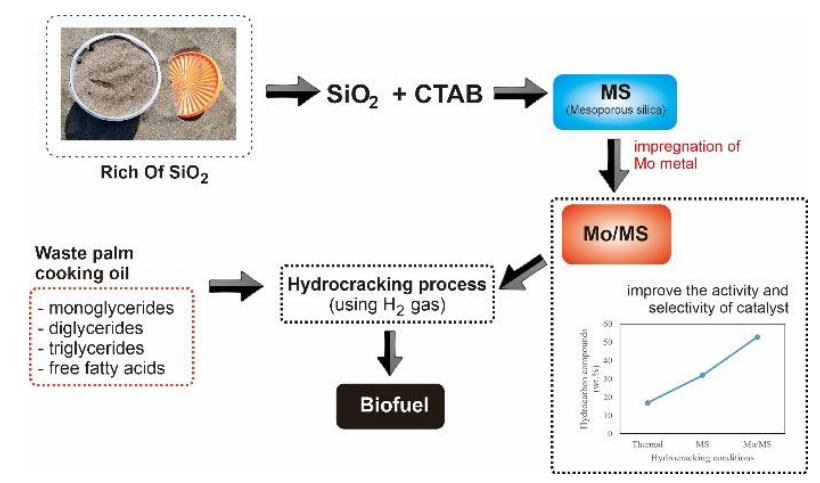

Keywords Mesoporous Silica, Molybdenum, Wet Impregnation Method, Waste Palm cooking oil, Hydrocracking, Reusable Catalyst

\section{Statement of Novelty}

Mesoporous silica such as SBA-15 and MCM-41 are known to be very expensive. This is what underlies this research using natural sources of Parangtritis beach sand which is known to have silica content which can be used as a source of silica. Parangtritis beach sand has never been used for anything. However, it is known to have a high enough silica content. So that this beach sand can be used for free. The silica obtained is synthesized into mesoporous silica by utilizing the CTAB template with ratio sodium silicate: CTAB of 1:0.5 (w/w). Mesoporous

*Corresponding author:

Wega Trisunaryanti

wegats@ugm.ac.id

1 Department of Chemistry, Faculty of Mathematics and Natural Sciences, Universitas Gadjah Mada, Yogyakarta 55281, Indonesia 
silica will be used as support for the embedded of Mo metal.

\section{Introduction}

Waste cooking oil is cooking oil that is used at high temperatures and edible fats mixed in kitchen waste [1]. Waste cooking oil is produced mostly by restaurants, household, food processing industries, and fast-food shops [2]. This waste cooking oil can be used as a biofuel [3,4]. Waste cooking oil contains organic molecules with long hydrocarbon chains such as fatty acids, triglycerides, and their derivatives $[3,5]$. The molecules with long-chain hydrocarbon in waste palm oil can be cracked into short-chain hydrocarbon molecules through a cracking process $[6,7]$.

Catalysts commonly used for catalytic cracking are heterogenous catalysts because easy separation, reusability, and environmental friendliness [8]. Catalytic cracking is a simple and cost-effective method that has become one of the most promising methods for producing biofuels. In addition, the pure triglyceride content is waste cooking oil does not affect the results of cracking products [9]. Metal oxides are more widely used in the hydrocracking process than other heterogenous catalysts. This is due to the structural properties characteristic of positive metal ions (cations) and negative oxygen ions (anions), which act as Lewis acids and Brønsted bases, respectively [9]. Mo metal has an active site that plays in the mechanism of the deoxygenation. The deoxygenation mechanism occurs during the hydrocracking process $[10,11]$. However, the use of Mo metal without support in the hydrocracking process can cause active metal sintering which reduces the catalytic stability [10]. One way to overcome this weakness is to use as a support that has strong metal-support interaction and a suitable containment of metal particles [12]. Therefore, this study uses mesoporous silica as support. The advantage of using mesoporous materials as support is involving the contribution of acid sites from metals that can increase the activity and selectivity of catalysts, such as mesoporous silica (MS) [13,14], SBA-15 [15], and MCM-41 [16]. The availability of this synthetic material is very limited and may also have an expensive price. Instead, an alternative is needed to obtain silica, namely by utilizing silica sources from Parangtritis beach sand. The sand as silica sources is a green catalyst that has good absorption activity $[17,18]$. Parangtritis beach sand, located in Yogyakarta, Indonesia, contains various types of metal oxides, one of which is $\mathrm{SiO}_{2}$, which will be the main constituent of the hydrocracking catalyst in this study. If this is possible it will bring great benefits to the environment because fewer chemical reagents are needed in the preparation of catalysis material. This is an interesting idea to investigate further.

Mesoporous silica such as SBA-15 impregnated in $\mathrm{Pt}$ metal can increase the production of the gasoline fraction by $72.8 \mathrm{wt} \%$ in the conversion of $n$-paraffin wax into biofuel [19]. Meanwhile, the use of NiMo-ZSM-5/MCM-41 catalyst for the conversion of crude palm oil (CPO) to biofuel was produced gasoline, kerosene, and diesel fractions of 13.6, 25.20, and 24.60 wt.\%, respectively [20].

Based on this consideration, in this study used the synthesis of mesoporous silica from Parangtritis beach sand templated by CTAB with impregnation Mo metal for hydrocracking waste palm cooking oil. The effect of hydrocracking condition including temperatures, catalyst: feed ratio, and catalyst reusability toward catalytic activity and selectivity for hydrocarbon compounds was evaluated.

\section{Experimental}

\subsection{Materials}

MS in this study was extracted from the Parangtritis beach sand collected in Yogyakarta, Indonesia. 
Sodium hydroxide $(\mathrm{NaOH}$ p.a) 6M, hydrochloric acid ( $\mathrm{HCl}$ p.a) 3M, metal precursors ammonium heptamolybdate tetrahydrate $\left(\left(\mathrm{NH}_{4}\right)_{6} \mathrm{Mo}_{7} \mathrm{O}_{24} \cdot 4 \mathrm{H}_{2} \mathrm{O}\right)$ and silver nitrate $\left(\mathrm{AgNO}_{3}\right) 0.1 \mathrm{M}$ were purchased from Merck. Waste palm cooking oil obtained collectively from domestic waste to be used as feed in the hydrocracking process.

\subsection{Sample preparation}

The synthesis of MS from Parangtritis beach sand was done in accordance the study by Kusumastuti et al. [21] The first step was to remove impurities in the Parangtritis beach sand. The $\mathrm{Cl}$ ions which can be transferred from seawater were removed by washing using distilled water. The $\mathrm{Cl}$ ions from seawater is a content of sodium chloride which must be removed because it is different from $\mathrm{Cl}$ ion from chemical reagents. The absence of $\mathrm{Cl}$ ions was tested by adding dropwise of $\mathrm{AgNO}_{3}$ to a washed sand filtrate solution, where removal of $\mathrm{Cl}$ ions was indicated in the absence of a white deposit formed. The chlorine-free sand was dried at $100{ }^{\circ} \mathrm{C}$ for $2 \mathrm{~h}$. Iron oxide contained the sand structure was separated by using magnets.

The second step was the extraction of MS from sand using the acid-base refluxed method. The sand was refluxed in $\mathrm{HCl}$ with a sand: $\mathrm{HCl}$ ratio of 1: 2 (w/v) at $90{ }^{\circ} \mathrm{C}$ for $3 \mathrm{~h}$. This was done to separate the alumina-silica bonds in the sand by dissolving the alumina in strong acid. Furthermore, the sand was refluxed using $\mathrm{NaOH}$ with sand: $\mathrm{NaOH}$ ratio of $1: 3$ (w/v) at $90^{\circ} \mathrm{C}$ for $5 \mathrm{~h}$. The sodium silicate obtained was added dropwise to the CTAB surfactant solution with a sodium silicate: CTAB ratio of 1:0.5 (w/w), the mixture was stirred for $2 \mathrm{~h}$ at ambient temperature. The mesoporous sodium silicate solution was added dropwise to the $2 \mathrm{M} \mathrm{HCl}$ until $\mathrm{pH}$ 10. The mixture was moved to an autoclave and the hydrothermal process was carried out at $100{ }^{\circ} \mathrm{C}$ for $24 \mathrm{~h}$. The resulting precipitate was filtered and washed with distilled water. After it was dried, material was calcined for $5 \mathrm{~h}$ at $550{ }^{\circ} \mathrm{C}$ to remove the CTAB templating agents.

The impregnation $\mathrm{Mo} / \mathrm{SM}$ was done using wet impregnation method. In the preparation of $\mathrm{Mo} / \mathrm{MS}$, $1 \mathrm{~g}$ of MS was dissolved in $30 \mathrm{~mL}$ a solution containing the precursor $\left(\mathrm{NH}_{4}\right)_{6} \mathrm{Mo}_{7} \mathrm{O}_{24} \cdot 4 \mathrm{H}_{2} \mathrm{O}$ at constant stirring for $24 \mathrm{~h}$. After mixing, water was evaporated from the mixture at $80{ }^{\circ} \mathrm{C}$. The material obtained was calcined under the flow $\mathrm{N}_{2}$ gas (20 $\mathrm{mL} / \mathrm{min}$ ) at $500{ }^{\circ} \mathrm{C}$ for $3 \mathrm{~h}$ with heating rate 5 ${ }^{\circ} \mathrm{C} / \mathrm{min}$, prior to reduction with $\mathrm{H}_{2}$ gas at $450{ }^{\circ} \mathrm{C}$ for $3 \mathrm{~h}$ with heating rate $5^{\circ} \mathrm{C} / \mathrm{min}$.

\subsection{Sample Characterization}

All catalyst functional groups were determined using Fourier Transform Infrared Spectrometer (FTIR) Shimadzu Prestige-21 with $\mathrm{KBr}$ disc technique at wavenumber 4000 to $400 \mathrm{~cm}^{-1}$. The crystallinity of the catalysts was characterized using X-ray Diffraction Bruker D2 Phaser $2^{\text {nd }}$ Gen. The surface area of all catalyst material was analyzed using surface area analyzer gas sorption Quantachrome NovaWin2 1200e version 2.2. The surface morphology catalyst was captured by Scanning Electron Microscopy (SEM) JEOL JSM 6510 and EDX was analyzed metal concentration total. The pore morphology was examined using Transmission Electron Microscopy (TEM) JEOLJEM-1400 microscope at $120 \mathrm{kV}$.

\subsection{Activity test}

The catalytic activity test was evaluated in the hydrocracking process of waste palm cooking oil, which was done in a semi-batch reactor system under $\mathrm{H}_{2}$ gas flow rate of $20 \mathrm{~mL} / \mathrm{min}$ for $2 \mathrm{~h}$. The catalytic activity was carried out at variations temperature of 500, 550, and $600{ }^{\circ} \mathrm{C}$, the catalyst: feed ratio of 1:100, 1:200, and 1:300 (w/w) and the reusability test with the best catalyst for the 
conversion of waste palm cooking oil. The producing liquid products were analyzed using Gas Chromatography-Mass Spectrometry (GC-MS) QP2010S. The activity (amount of hydrocracking product) will be calculated as follow:

The liquid $(\%)=\frac{W_{L P}(g)}{W_{W P O}(g)} \times 100 \%$

The residue $(\%)=\frac{W_{R}(g)}{W_{W P O}} \times 100 \%$

The coke $(\%)=\frac{W_{C}(g)}{W_{W P O}(g)} \times 100 \%$

The gas $(\%)=\frac{W_{W P O}(g)-W_{L}(g)-W_{C}(g)}{W_{W P O}(g)} \times 100 \%$

Total conversion $(\%)=\frac{W_{W P O}(g)-W_{R}(g)}{W_{W P O}(g)} \times 100 \%$

Where $\mathrm{W}_{\mathrm{LP}}$ is the weight of the liquid product, $\mathrm{W}_{\mathrm{WPO}}$ is the weight of the waste palm cooking oil, $\mathrm{W}_{\mathrm{R}}$ is the weight of the residue, and $\mathrm{W}_{\mathrm{C}}$ is the weight of the coke.

The biofuel conversion selectivity will be calculated using the equation below:

Total biofuel conversion $=$ Amount of diesel and gasoline

Table 1 Hydrocracking reactor condition

\begin{tabular}{lll}
\hline Condition type & Initial & Final \\
\hline $\mathrm{H}_{2}$ gas flow rate & $20 \mathrm{~mL} / \mathrm{menit}$ & $20 \mathrm{~mL} / \mathrm{menit}$ \\
\hline Temperature 1 & $25^{\circ} \mathrm{C}$ & $500^{\circ} \mathrm{C}$ \\
\hline Temperature 2 & $25^{\circ} \mathrm{C}$ & $550{ }^{\circ} \mathrm{C}$ \\
\hline Temperature 3 & $25^{\circ} \mathrm{C}$ & $600^{\circ} \mathrm{C}$ \\
\hline
\end{tabular}

\section{Results and discussion}

\subsection{Characterization of the Catalysts}

In this study, mesoporous silica (MS) was synthesized from Parangtritis beach sand. The synthesized MS has a purity of 99.76 wt.\%. The MS was used a support.

Characterization of functional groups from MS and Mo/MS catalysts by FTIR is shown in Fig.1. Around the wavenumbers of 406, 804, and $1085 \mathrm{~cm}^{-}$ 1 are found the $\mathrm{Si}-\mathrm{O}-\mathrm{Si}$ bending vibrations.
Hereinafter, it can be seen that there is bending and stretching vibration $\mathrm{Si}-\mathrm{OH}$ around the wavenumber of $1635-3448 \mathrm{~cm}^{-1}$, respectively [22,23]. This proved that the MS synthesis from Parangtritis beach sand was successful.

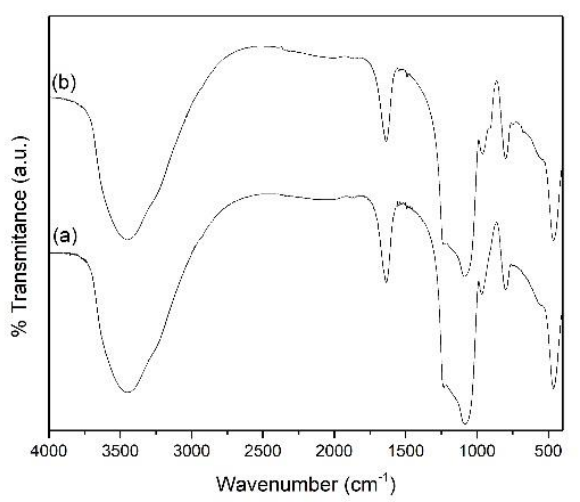

Fig. 1 Infrared spectra of (a) MS (b) Mo/MS catalysts

The diffraction pattern of MS and Mo/MS are presented in Fig.2. The diffraction of MS has a broad peak that appears at $2 \theta=28^{\circ}(101)$ which indicates that $\mathrm{MS}$ is an amorphous material [24]. $\mathrm{Mo} / \mathrm{SM}$ catalysts have diffraction peaks at $12.3^{\circ}, 23.3^{\circ}$, $26.6^{\circ}, 36.1^{\circ}$, and $53.8^{\circ}$, indexed as (001), (100), (101), (102) and (202) (JCPDS card no. 01-081067). This indicates that the peaks are the characteristics peaks of $\mathrm{MoO}_{3}$ [25,26]. These results confirm that Mo metal was successfully impregnated on MS. The crystallite size of $\mathrm{Mo} / \mathrm{MS}$ catalyst was calculated using Scherer equation. The broad peak observed at $2 \theta=26.6^{\circ}$ indicates a high peak intensity which may be due to thin layer of Mo species present on the MS support, so that the peak will determine the crystallite size of the Mo metal $[27,28]$. The Mo/MS catalyst had an average crystallite $\mathrm{MoO}_{3}$ size of $41.98 \mathrm{~nm}$. 


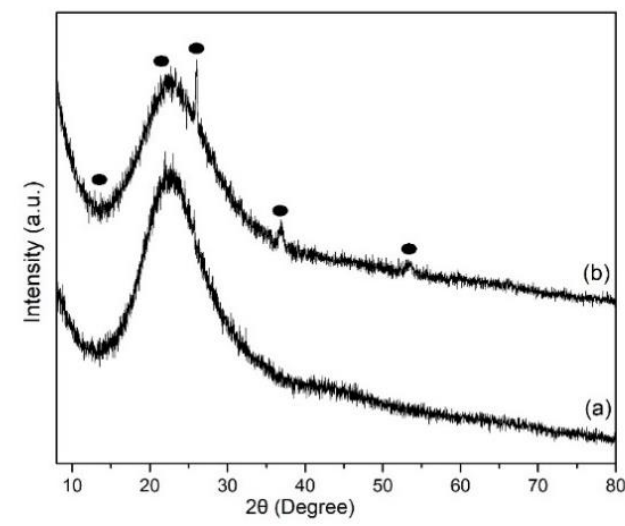

Fig. 2 Diffraction pattern of (a)MS and Mo/MS catalyst
The porosity of MS and Mo/MS catalyst is presented in Table 2. After the metal Mo impregnation process, it can be seen that the surface area of the catalyst decreased. This may be caused the Mo metal was evenly distributed in the MS pores. In addition, the pore diameter and pore volume of the catalyst also decreased. This is due to the blocking of the catalyst pores by the metal Mo.

Table 2 Characteristic of the catalysts

\begin{tabular}{cccccc}
\hline Sample & $\begin{array}{c}\text { Surface area } \\
\left(\mathrm{m}^{2} / \mathrm{g}\right)^{*}\end{array}$ & $\begin{array}{c}\text { Average pore } \\
\text { diameter }(\mathrm{nm})^{*}\end{array}$ & $\begin{array}{c}\text { Total pore } \\
\text { volume }(\mathrm{cc} / \mathrm{g})^{*}\end{array}$ & $\begin{array}{c}\text { Concentration of } \\
\text { Mo }(\%)\end{array}$ & $\begin{array}{c}\text { Crystallite size } \\
(\mathrm{nm})\end{array}$ \\
\hline MS & 897.3 & 2.62 & 0.8252 & No detected & No detected \\
Mo/MS & 593 & 2.46 & 0.6386 & 4.75 & 41.98 \\
\hline
\end{tabular}

*Surface area, average diameter pore and total pore volume of the sample were calculated using BET, BJH, and DR, respectively

The nitrogen adsorption/desorption isotherm of the MS and MS/Mo catalyst are shown in Fig. 3. The figure shows that all catalyst including a type IV isotherm (based on IUPAC classification), with the hysteresis loop type H1. This suggests that MS and $\mathrm{Mo} / \mathrm{MS}$ catalyst are mesoporous materials. In Figure

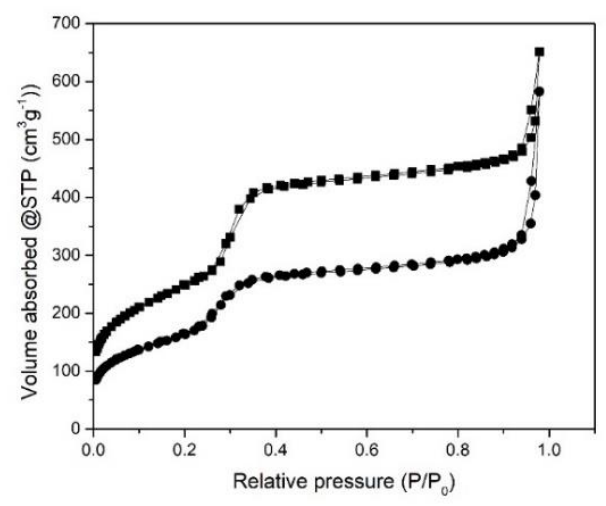

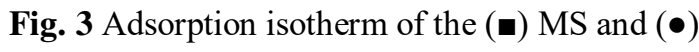
Mo/MS catalyst

The morphology of the MS and Mo/MS catalysts is represented in Fig.5. SEM micrographs of MS show a uniform and homogenous surface.
4, it can be seen that Mo metal is evenly distributed in MS. This is what causes a decrease in the Mo/MS. The pore size distribution presented in Fig. 4 supports the results of the $\mathrm{Mo} / \mathrm{MS}$ surface area shown in Table 2.

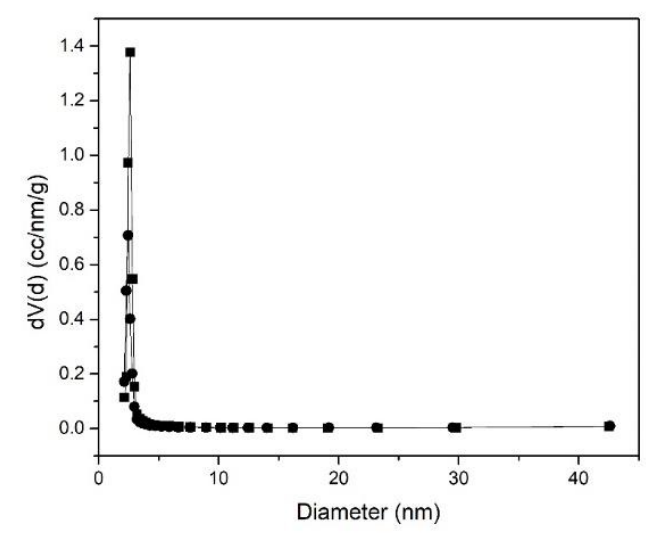

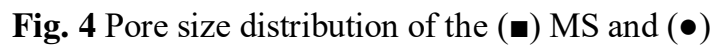
$\mathrm{Mo} / \mathrm{SM}$ catalysts

The impregnation of Mo metal causes agglomeration. This is one of the causes of decreased surface area. In addition, Fig $5 b$ shows 
that molybdenum oxide is well supported and distributed on silica. The comparison of these two figures shows that $\mathrm{MoO}_{3}$ is strongly adsorbed on the mesoporous silica surface [29]. Table 2 indicates the total impregnated metal concentrations. The

\subsection{Catalytic Activity of MS and Mo/MS}

The activity and selectivity tested of MS and $\mathrm{Mo} / \mathrm{MS}$ catalysts were carried out at $500{ }^{\circ} \mathrm{C}$ with a catalyst: feed ratio of $1: 100$. The feed used in this research was waste palm cooking oil. In this study, thermal cracking was done as a comparison. The distribution of hydrocracking products is shown in Table 2 using waste palm cooking oil as feed. The catalyst with the best activity and selectivity will be studied further to determine the optimum conditions for the hydrocracking process. impregnated Mo metal concentrations on MS was $4.75 \%$. Mo metal concentrations under $5 \%$ were able to produce the best catalyst activity and selectivity [30].
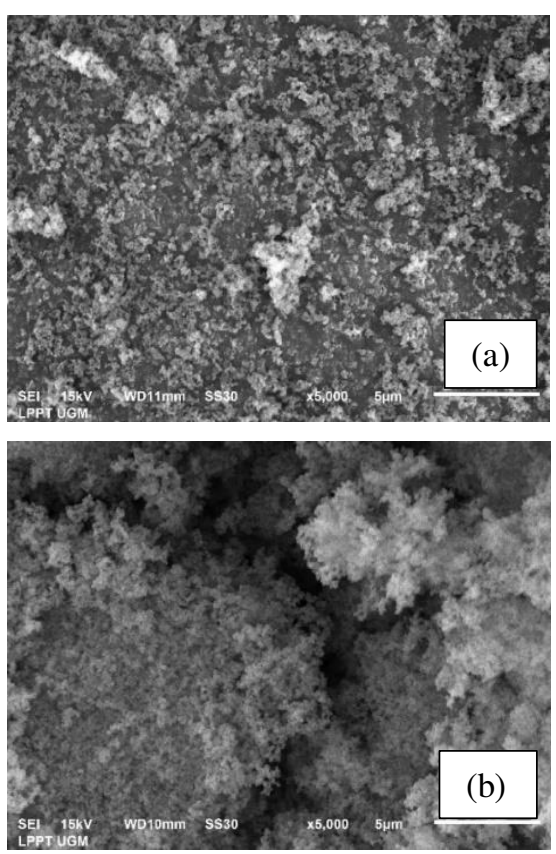

Fig. 5 Morphology of (a) MS and (b) MS/Mo catalysts

Table 3 Hydrocracking product of waste palm cooking oil

\begin{tabular}{cccccc}
\hline \multirow{2}{*}{$\begin{array}{c}\text { Hydrocracking } \\
\text { conditions }\end{array}$} & \multicolumn{3}{c}{ Conversion (wt.\%) } & $\begin{array}{c}\text { Total } \\
\text { conversion } \\
\text { (wt.\%) }\end{array}$ \\
\cline { 2 - 5 } & Liquid product & Gas product & Residue & Coke $^{2}$ & 61.84 \\
Thermal & 19.15 & 42.68 & 38.16 & 0 & 72.2 \\
MS & 38.38 & 32.42 & 27.78 & 1.42 & 91.81 \\
Mo/MS & 60.93 & 29.44 & 8.19 & 1.43 & \\
\hline
\end{tabular}

${ }^{1}$ Residue is the residue waste palm oil that is not converted into biofuel.

${ }^{2}$ Coke is waste palm oil that is deposited on the surface of the catalyst which cannot be converted into biofuel.

Thermal cracking produces less liquid product than catalytic cracking. This may be due to the formation of radical ions which were influenced by relatively high temperatures. Radical ions formed at the initiation stage of thermal cracking break the carbon bonds at the $\beta$ position and form new radical compounds with less of carbon atoms so that thermal cracking produces more gas product compared to catalytic hydrocracking [21]. However, it was observed that the MS catalyst still produced a high enough gas product which decreased the liquid product. Thus, Mo metal impregnation was done to increase the catalyst activity. The presence of Mo metal decreases the gas product and increases the liquid product. This is because Mo metal has an active site, which is due to the presence of unpaired electrons in the $\mathrm{d}$ orbitals. The unpaired electrons in the $\mathrm{d}$ orbitals can be dissociate hydrogen gas in a homolytic, which will be required in the hydrocracking process $[14,21,31]$. In addition, the 
impregnation of Mo metal caused an increase in coke although not significant. This can be caused by waste palm cooking oil that cannot be absorbed by the catalyst or deposited on the catalyst. The decrease in surface area, the more effective in the contact between the waste palm cooking oil as feed and the catalyst $[32,33]$.

Waste palm oil is generally a mixture of triglycerides and free fatty acids (FFA) [3]. Conversion of triglycerides to hydrocarbons requires the removal oxygen from waste palm cooking oil, which is known as the deoxygenation reaction [34]. Deoxygenation reactions include three different pathways type of decarbonylation, decarboxylation, or hydrodeoxygenation [35].
Decarboxylation/decarbonylation is the removal one carbon from the ester chain in the form carbon dioxide and the reduction stops in the production of aldehydes/ketones. Whereas the reduction hydrodeoxygenation continues to form alcohol compounds [13,36]. After observing MS and Mo/MS, the hydrocracking process occurred through a decarboxylation/decarbonylation mechanism. This is due to the absence of alcohol compounds so that it can be concluded that the reduction stops in the production of aldehydes/ketones. Other oxygenate compounds are too high, it is possible for imperfect cracking occur during the hydrocracking process.

Table 4 The selectivity of the catalyst toward the liquid product

\begin{tabular}{ccccccc}
\hline $\begin{array}{c}\text { Hydrocracking } \\
\text { conditions }\end{array}$ & \multicolumn{6}{c}{ Fraction in a liquid product (wt.\%) } \\
\cline { 2 - 6 } & $\begin{array}{c}\text { Gasoline } \\
\left(\mathrm{C}_{5}-\mathrm{C}_{12}\right)\end{array}$ & $\begin{array}{c}\text { Diesel } \\
\left(\mathrm{C}_{13^{-}}\right. \\
\left.\mathrm{C}_{17}\right)\end{array}$ & $\begin{array}{c}\text { Free } \\
\text { fatty } \\
\text { acids }\end{array}$ & Aldehydes/Ketones & $\begin{array}{c}\text { Other } \\
\text { oxygenates }\end{array}$ & $\begin{array}{c}\text { Total biofuel } \\
\text { conversion (wt.\%) }\end{array}$ \\
\hline Thermal & 15.59 & 1.17 & 1.16 & 0.44 & 1.17 & 16.76 \\
MS & 20.83 & 11.09 & - & 0.88 & 5.59 & 31.92 \\
Mo/MS & 25.97 & 26.85 & - & 0.64 & 7.48 & 52.82 \\
\hline
\end{tabular}

\subsection{Effect of Temperature and Catalyst: Feed}

\section{Ratio}

Although it was known that the Mo/MS catalyst was able to covert waste palm cooking oil by 91.81 wt.\%. However, Mo/MS catalyst can still increase its activity and selectivity by selecting the best temperature and the most suitable catalyst: feed ratio. As shown in Table 5, the highest liquid product conversion results in catalytic hydrocracking at $550{ }^{\circ} \mathrm{C}$. The conversion resulted in an increase of more than $3 \mathrm{wt} \%$ compared to hydrocracking at $500{ }^{\circ} \mathrm{C}$. In addition, coke was produced at $550^{\circ} \mathrm{C}$ to $0.05 \mathrm{wt} . \%$. This shows that the best temperatures were $550{ }^{\circ} \mathrm{C}$.

The best temperature variation activity test at $550{ }^{\circ} \mathrm{C}$ generates a liquid product of $63.95 \mathrm{wt} \%$. This proves that increasing the temperature in the hydrocracking process can increase the performance of the catalyst in producing liquid products [37]. However, at $600{ }^{\circ} \mathrm{C}$, the resulting liquid product decreases because the gas production was higher. It seems that hydrocracking at higher temperatures results in a higher gas fraction. This behavior can be attributed to the fact that higher temperatures accelerate thermal decomposition, then will crack long-chain hydrocarbons into lighter hydrocarbon molecules [38]. This increase in the liquid product can be related to a shift in the selectivity of the deoxygenation mechanism which results in heavier hydrocarbons (Table 6). The further hydrogenation of the alcohol will produce long-chain hydrocarbons by means of the hydrodeoxygenation mechanism [14]. 
Table 5 Effect of temperature and catalyst: feed ratio toward product distribution

\begin{tabular}{|c|c|c|c|c|c|}
\hline \multirow[t]{2}{*}{ Variation } & \multicolumn{4}{|c|}{ Conversion (wt.\%) } & \multirow{2}{*}{$\begin{array}{c}\text { Total } \\
\text { conversion } \\
\text { (wt. \%) }\end{array}$} \\
\hline & Liquid product & Gas product & Residue $^{1}$ & Coke $^{2}$ & \\
\hline \multicolumn{6}{|c|}{ Variations of temperature with catalyst: feed 1:100 } \\
\hline $500^{\circ} \mathrm{C}$ & 60.93 & 29.43 & 8.18 & 1.43 & 91.80 \\
\hline $550^{\circ} \mathrm{C}$ & 63.95 & 32.30 & 3.69 & 0.05 & 96.31 \\
\hline $600^{\circ} \mathrm{C}$ & 54.78 & 43.22 & 1.99 & 0.004 & 98.01 \\
\hline \multicolumn{6}{|c|}{ Variations of catalyst: feed with temperature $550^{\circ} \mathrm{C}$} \\
\hline $1: 200$ & 64.12 & 8.90 & 26.81 & 0.16 & 73.19 \\
\hline $1: 300$ & 66.99 & 10.46 & 22.53 & 0.03 & 77.47 \\
\hline
\end{tabular}

${ }^{1}$ Residue is the residue waste palm oil that is not converted into biofuel.

${ }^{2}$ Coke is waste palm oil that is deposited on the surface of the catalyst which cannot be converted into biofuel.

Based on Table 6, it can be seen that temperature variations in the hydrocracking process can affect the selectivity of the catalyst. The total hydrocarbon compound produced at $500{ }^{\circ} \mathrm{C}$ was 52.82 wt.\%, but with an increase in temperature of up to $550{ }^{\circ} \mathrm{C}$, the total hydrocarbon yield increased to $60.12 \mathrm{wt} . \%$. However, an increase in temperature of up to $600{ }^{\circ} \mathrm{C}$, the total hydrocarbon compounds decreased to 47.22 wt.\%. This was related to the generating liquid product [14].

Table 6 Selectivity of the catalyst toward the liquid product

\begin{tabular}{|c|c|c|c|c|c|c|c|c|}
\hline \multirow[t]{2}{*}{ Variation } & \multicolumn{7}{|c|}{ Fraction in a liquid product (wt.\%) } & \multirow[b]{2}{*}{$\begin{array}{c}\text { Total biofuel } \\
\text { conversion (wt.\%) }\end{array}$} \\
\hline & $<\mathrm{C} 5$ & $\begin{array}{l}\text { Gasoline } \\
\left(\mathrm{C}_{5}-\mathrm{C}_{12}\right)\end{array}$ & $\begin{array}{l}\text { Diesel } \\
\left(\mathrm{C}_{13^{-}}\right. \\
\left.\mathrm{C}_{17}\right)\end{array}$ & $\begin{array}{l}\text { Free } \\
\text { fatty } \\
\text { acids }\end{array}$ & $\begin{array}{l}\text { Aldehydes/ } \\
\text { Ketones }\end{array}$ & Alcohol & $\begin{array}{l}\text { Other } \\
\text { oxygenates }\end{array}$ & \\
\hline \multicolumn{9}{|c|}{ Variations of temperature with catalyst: feed 1:100 } \\
\hline $500{ }^{\circ} \mathrm{C}$ & - & 25.97 & 26.85 & - & 0.64 & - & 7.48 & 52.82 \\
\hline $550{ }^{\circ} \mathrm{C}$ & 1.31 & 24.35 & 35.77 & - & 0.87 & 0.87 & 0.79 & 60.12 \\
\hline $600{ }^{\circ} \mathrm{C}$ & - & 41.82 & 5.40 & 1.41 & 2.99 & 2.99 & 2.57 & 36.42 \\
\hline \multicolumn{9}{|c|}{ Variations of catalyst: feed with temperature $550^{\circ} \mathrm{C}$} \\
\hline $1: 200$ & - & 22.12 & 38.27 & 0.67 & 2.21 & 0.87 & - & 60.39 \\
\hline $1: 300$ & - & 24.54 & 38.34 & - & 2.26 & - & 1.84 & 62.79 \\
\hline
\end{tabular}

Table 5 shows that the more feeds used, the more liquid product will be produced during the hydrocracking process. Despite the catalyst: feed ratio resulted in lower total conversions. This behavior proves that the Mo/MS catalyst was able to convert waste palm cooking oil into biofuel with a ratio variation of the catalyst: feed of 1:300, where the more feed used in the hydrocracking process can increase the produced liquid product [37].

Residue increase was occurred during catalytic hydrocracking waste palm cooking oil at various catalyst: feed. This is because the catalyst will naturally be more occupied and crowded with more feed entering the pores of the catalyst. Nevertheless, a catalyst with a temperature of $550{ }^{\circ} \mathrm{C}$ and a catalyst: feed ratio of 1:300 was given a higher hydrocarbon product, so was preferred. The reaction mechanism that occurred at various catalyst: feed ratios 1:300 and 1:200 was a decarboxylation/ decarbonylation reaction mechanism.

\subsection{Reusability of Mo/MS catalyst}

The Mo/MS catalyst stability test was carried out 3 runs for the hydrocracking of waste palm cooking oil at temperature of $550{ }^{\circ} \mathrm{C}$ and ratio of catalyst: feed 1:300. During 3 runs, the Mo/MS catalyst was shown to provide the best activity and selectivity with high conversion levels. 
Table 7 Effect of Mo/MS catalyst reusability toward product distribution

\begin{tabular}{cccccc}
\hline Catalyst & \multicolumn{3}{c}{ Conversion (wt.\%) } & $\begin{array}{c}\text { Total } \\
\text { conversion } \\
\text { (wt.\%) }\end{array}$ \\
\cline { 2 - 5 } & Liquid product & Gas product & Residue & Coke & 77.47 \\
\hline $\mathrm{Mo} / \mathrm{MS}^{1}$ & 66.99 & 10.46 & 22.53 & 0.03 & 89.86 \\
$\mathrm{Mo} / \mathrm{MS}^{2}$ & 68.51 & 21.28 & 10.13 & 0.07 & 94.46 \\
$\mathrm{Mo} / \mathrm{MS}^{3}$ & 80.26 & 11.55 & 5.54 & 2.64 & \\
\hline
\end{tabular}

${ }^{1}$ The first hydrocracking used a Mo/MS catalyst

${ }^{2}$ The second hydrocracking used a Mo/MS catalyst

${ }^{3}$ The third hydrocracking used a Mo/MS catalyst

Table 7 shows that the liquid product after reusability test the third catalyst is $80.26 \mathrm{wt} \%$, which indicates a significant increase in the liquid product compared to the first and second used catalysts. The formation of coke also appears to be relatively high, indicating stability to coke poisoning. Increasing the amount of coke on the surface of the catalyst can block the active site of catalyst where the deoxygenation mechanism occurs take place. The deactivation of the catalyst occurs due to the formation coke which is deposited on the active site of the catalyst [39]. Interestingly, after the third reusability test, the residue decreased. This may be due to weakened adsorption by oxygen vacancies in the presence of coke which possible a faster flow of feed molecules through the catalyst pores. The total conversion of cracking product is

the sum of liquid products, gas products, and coke [40], so coke formation also increases the total product conversion. In addition, an increase in the gas fraction in the second catalyst reusability test was another indication that the cracking was less controlled and localized due to possible deactivation of the adsorption site in the catalyst. The removal of free fatty acids levels on the catalyst reuse was found in the liquid product which showed increased effectiveness in catching oxygenate compound. Thus, the use of the catalyst 3 times has not seen a decrease in hydrocarbon compound. However, it is possible that after using more than 3 times, there will be a decrease in hydrocarbon compounds. This can also be seen from the higher coke formation (Table 6) which will affect the conversion results of liquid products and hydrocarbon compounds [41].

Table 8 Selectivity of the Mo/MS catalyst reused toward the liquid product

\begin{tabular}{|c|c|c|c|c|c|c|c|c|c|}
\hline \multirow[t]{2}{*}{ Variations } & \multicolumn{8}{|c|}{ Fraction in a liquid product (wt.\%) } & \multirow{2}{*}{$\begin{array}{l}\text { Total } \\
\text { biofuel } \\
\text { conversion } \\
\text { (wt.\%) }\end{array}$} \\
\hline & $<\mathrm{C}_{5}$ & $\begin{array}{l}\text { Gasoline } \\
\left(\mathrm{C}_{5}-\mathrm{C}_{12}\right)\end{array}$ & $\begin{array}{c}\text { Diesel } \\
\left(\mathrm{C}_{13^{-}}\right. \\
\mathrm{C}_{17)}\end{array}$ & $>\mathrm{C}_{17}$ & $\begin{array}{l}\text { Free } \\
\text { fatty } \\
\text { acids }\end{array}$ & $\begin{array}{c}\text { Aldehydes/ } \\
\text { Ketones }\end{array}$ & Alcohol & $\begin{array}{c}\text { Other } \\
\text { oxygenates }\end{array}$ & \\
\hline $\mathrm{Mo} / \mathrm{MS}^{1}$ & - & 24.54 & 38.34 & - & 2.26 & - & 1.84 & - & 62.88 \\
\hline $\mathrm{Mo} / \mathrm{MS}^{2}$ & 1.14 & 25.41 & 40.19 & - & - & 0.99 & 0.80 & - & 65.6 \\
\hline $\mathrm{Mo} / \mathrm{MS}^{3}$ & - & 28.98 & 45.15 & 0.59 & - & 3.17 & 0.96 & 1.39 & 74.13 \\
\hline \multicolumn{10}{|c|}{$\begin{array}{l}{ }^{1} \text { The first hydrocracking used a Mo/MS catalyst } \\
{ }^{2} \text { The second hydrocracking used a Mo/MS catalyst } \\
{ }^{3} \text { The third hydrocracking used a Mo/MS catalyst }\end{array}$} \\
\hline \multicolumn{6}{|c|}{$\begin{array}{l}\text { The morphology of Mo/MS catalyst before and } \\
\text { er hydrocracking is shown Fig.6. It can be seen in }\end{array}$} & \multicolumn{4}{|c|}{$\begin{array}{l}\text { molybdenum which becomes darker. This suggests } \\
\text { that coke formation affected deactivation of the } \\
\text { catalyst. }\end{array}$} \\
\hline
\end{tabular}

which show that the material is still not agglomeration. In Fig.6 (b) and (c) it is after the first and third used that it shows the presence of black spots and agglomeration. The black spots are 

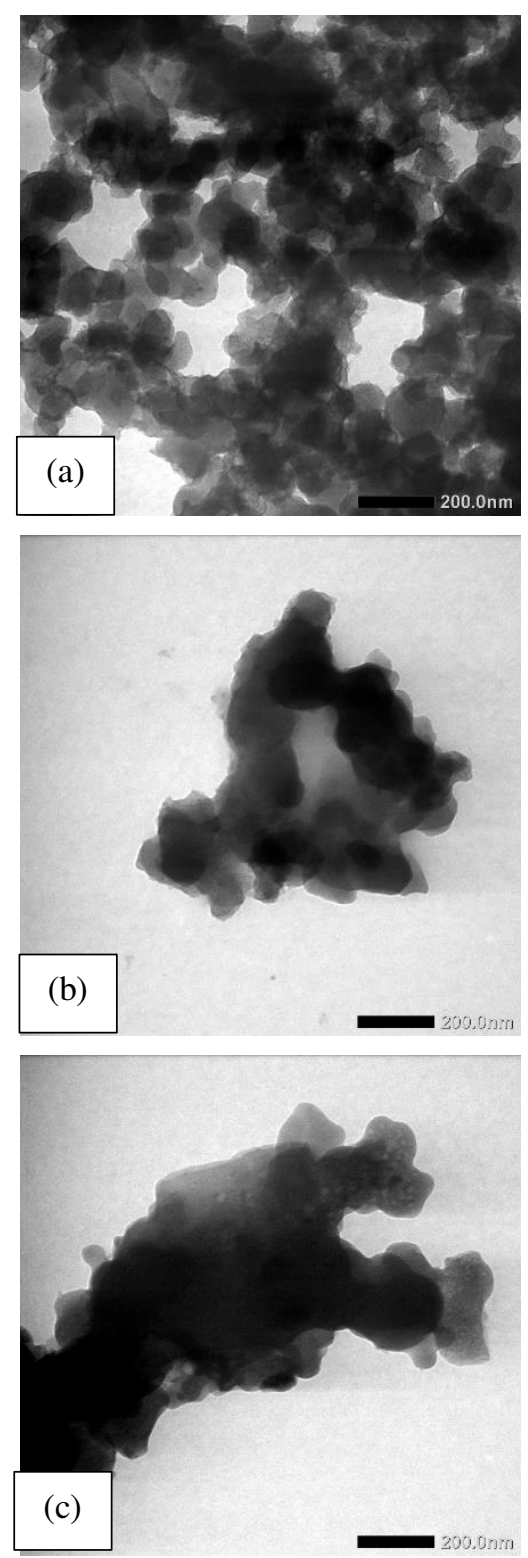

Fig. 6 TEM images of MS/Mo (a) fresh (b) after one-time hydrocracking (c) after three-time hydrocracking

\section{Conclusions}

This research has been successful that synthesis of MS from Parangtritis beach sand using CTAB template. MS synthesis has a large surface area of $897.3 \mathrm{~m}^{2} / \mathrm{g}$ and pore diameter of $2.62 \mathrm{~nm}$. Mo metal impregnation on MS was done to increase the catalyst activity and selectivity for the hydrocracking process of waste palm cooking oil into biofuel. Mo metal impregnation decreased surface area, pore diameter, and pore volume to 593 $\mathrm{m}^{2} / \mathrm{g}, 2.46 \mathrm{~nm}$, and $0.6386 \mathrm{cc} / \mathrm{g}$, respectively. The amount of impregnated Mo metal was $4.75 \%$. Mo/MS catalyst was the catalyst with the best activity and selectivity at temperature optimum of $550{ }^{\circ} \mathrm{C}$ and catalyst: feed ratio of 1:300 which has a liquid product and total hydrocarbon compound of 66.99 and 62.79 wt.\%, respectively. The catalyst reusability test gave very good results, where the use catalyst 3 runs did not decrease the activity and selectivity of the catalyst. The third reusability test produced liquid products and total hydrocarbon compound of 80.26 and 74.13 wt. $\%$.

Funding Statement This scientific publication is funded by the Universitas Gadjah Mada Indonesia

Acknowledgments The authors would like to thank the Universitas Gadjah Mada Indonesia for the financial support of Rekognisi Tugas Akhir Universitas Gadjah Mada

\section{Compliance with Ethical Standards}

Conflict of interests The authors declare that they have no conflict of interest.

\section{Consent to Participate}

All authors have made a significant contribution to this manuscript, have seen and approved the final manuscript.

\section{Consent for Publication}

All authors have agreed to submit this manuscript to the Journal of Porous Materials.

\section{Availability of Data and Material}

Data and materials are available and prepared, authors will be pleased to provide it if requested during the publication process. 


\section{Author Contributions}

Gesha Desy Alisha: Investigation, Methodology, Formal analysis, Visualization, Writing - original draft. Wega Trisunaryanti: Conceptualization, Supervision, Resources, Methodology, Writing review \& editing. Akhmad Syoufian: Investigation, Validation.

\section{References}

1. Zhang, H., Wang, Q., Mortimer S.R.: Waste cooking oil as an energy resources: Review of Chinese policies. Renew. Sustain. Energ. Rev. 16, 5225-5231 (2012). https://doi.org/10.1016/j.rser.2012.05.008

2. Sanjid, A., Masjuki, H.H., Kalam, M.A., Rahman, S.M.A., Abedin, M.J., Palash, S.M.: Impact of palm mustard, mustard, waste cooking oil and Calophylum inophylum biofuels on performance and emission of $\mathrm{Cl}$ engine. Renew. Sustain. Energ. Rev. 27, 664-682 (2013). https://doi.org/10.1016/j.rser.2013.07.059

3. Chuepeng, S., Komintarachat, C.: Insterfication otimization of waste cooking oil and ethyl acetate over homogeneous catalyst for biofuel production with engine validation. Appl. Energy 232, 728-739 (2018)

https://doi.org/10/1016/j.apenergy.2018.09. 085

4. Wang, Y., Cao, Y., Li, J.: Preparation of biofuels with waste cooking oil by fluid catalytic cracking: The effect of catalyst performance on the products. Renew. Energ. 124, 34-39 (2018). https://doi.org/10.1016/j.renene.201708.08 4

5. Trabelsi, A.B.H., Zaafouri, K., Baghdadi, W., Naoui, S., Ouerghi, A.: Second generation biofuels production from waste cooking oil via pyrolisis process. Renew.

Energ. 126, 888-896 (2018). https://doi.org/10.1016/j.renene.2018.04.00 2

6. Barrón, A.,E., Melo-Banda, J.A., Dominguez, J.M., Hernández, E., Silva. R., T. Reyes A.I., M. Meraz M.A.: Catalytic hydrocracking of vegetable oil agrofuels production using Ni-Mo, Ni-W, Pt , dan TFA catalysts supported on SBA-15. Catal. Today 166, 102-110 (2011). https://doi,org/10.1016/j.cattod.2011.01.02 6

7. Dik, P.P., Danilova, I.G., Golubev, I.S., Kazakov, M.O., Nadeina, K.A., Budukva, S.V., Pereyma, V.Y., Klimov, O.V., Prosvirin, I.P., Gerasimov, E.Y., Bok, T.O., Dobryakova, I.V., Knyazeva, E.E., Ivanova, I.I., Noskov, A.S.: Hydrocracking of vacuum gas oil over NiMo/zeolite- $\mathrm{Al}_{2} \mathrm{O}_{3}$ : Influence of zeolite properties. Fuel 237, 178-190 https://doi.org/10.1016/j.fuel.2018.10.012

8. Kim, H., Kang, B., Kim, M., Park, Y.M., Kim, D., Lee, J., Lee, K.: Transesterification of vegetable oil to biodiesel using heterogeneous base catalyst. Catal. Today 95, $315-320$ https://doi.org/10.1016/jcattod.2004.06.007 9. Cao, X., Li, L., Yu, S., Liu, S., Yu, H., Wu, Q.: Catalytic conversion of waste cooking oils for the production of liquid hydrocarbon biofuels using in-situ coating metal oxide on SBA-15 as heterogeneous catalyst. J. Anal. Appl. Pyrolisis 138, 137-144 (2019). https://doi.org/10.1016/j.jaap.2018.12.017

10. Santi, D., Trisunaryanti, W., Falah, I.I.: Hydrocracking of pyrolyzed $\alpha$-cellulose to hydrocarbon over $\mathrm{M}_{\mathrm{x}} \mathrm{O}_{\mathrm{y}} /$ Mesoporous carbon catalyst $(\mathrm{M}=\mathrm{Co}$ and $\mathrm{Mo})$ : Synthesis 
and characterization of carbon based catalyst support from saw waste of Merbau. J. Environ. Chem. Eng. 8, 103735 (2020). https://doi.org/10.1016/j.jece.2020.1037

11. Shin, S., Lee, J.H., Jo, Y.K., Nguyen, M.T., Park, B.K., Park, S., Lee, C.W., Kim, C.G., Chung, T.: Synthesis noble molybdenum and tungsten complexes for hydrocracking catalyst of heavy oil. J. Ind. Eng. Chem. 72, 408-413 https://doi.org/10.1016/j.jiec.2018.12.043

12. Ramesh, A., Tamizhdurai, P., Krishnan, P.S., Ponnusamy, V.K., Sakthianthan, S., Shanthi, K.: Catalytic transformation of non edible oils tobiofuels through hydrodeoxygenation using Mo-Ni mesoporous alumina-silica catalysts. Fuel 262 116494 https://doi.org/10.1016/j.fuel.2019.116494

13. Infantes-Molina, A., Mérida-Robles, J., Rodríguez-Castellón, E., Pawelec, B., Fierro, J.L.G., Jiménez-López, A.: Catalyst based on Co/zirconium doped mesoporous silica MSU for the hydrogenation and hydrogenolysis/hydrocracking of tetralin. Applied Catalysis A: General 286, 239-248 (2007).

https://doi.org/10.1016/j.apacata.2005.03.0 22

14. Trisunaryanti, W., Larasati, S., Bahri, S., Ni'mah, Y.L., Efiyanti, L., Amri, K., Nuryanto, R., Sumbogo, S.D.: Performance comparison of $\mathrm{Ni}-\mathrm{Fe}$ loaded on $\mathrm{NH}_{2}-$ functionalized mesoporous silica and beach sand in the hydrotratment of waste palm cooking oil. J. Environ. Chem. Eng. 8, 104477 https://doi.org/10.1016/j.jece.2020.104477

15. Jiang, B., Zhu, T., Song, H., Li, F.: Hydrodeoxygenation and hydrodesulfurization over $\mathrm{Fe}$ promoted $\mathrm{Ni}_{2} \mathrm{P} / \mathrm{SBA}-15$ catalyst. J. Alloys Compd. 806, 254-262 htpps://doi.org//10.1016/j.alcom.2019.07.2 42

16. Barbosa, F.A., Santos, A.C.B., Silva, M.I.P., Stumbo, A.M.: Resistance to poisoning by nitrogen compounds of NiMo/Al-MCM-41 hydrocracking catalysts. Catal. Today 98, 109-113 (2004). https:// doi.org/10.1016/j.cattod.2004.07.025

17. Seo, M., Lee, D., Lee, K., Moon, D.J.: Pt/AlSBA-15 catalysts for hydrocracking of $\mathrm{C}_{21^{-}}$ $\mathrm{C}_{34}$ n-paraffin mixture into gasoline and diesel fractions. Fuel 143, 63-71 (2015). https://doi.org/10.1016/j.fuel.2014.11.028

18. Dar, A.D., Mohsin, M., Basit, A., Farooqui, M.: Sand: A natural and potential catalyst in renowned Friedel Craft's acylation of aromatic compounds. J. Saudi Chem. Soc. 17(2), 177-180 (2013). https:// doi.org/10.1016/j.jscs.2011.03.004

19. Darghouth, A., Aouida, S., Bessais, B.:High purity porous silicon powder synthesis by magnesiothermic reduction of Tunisian silica sand. Silicon. 13, 667-676 (2021). https://doi.org/10.1007/s12633-020-004331

20. Subsadsana, M., Kham-or, P., Sangdara, P., Suwannasom, P., Ruangviriyachai, C.: Synthesis and catalytic performance of biometallic NiMo- and NiW-ZSM-5/MCM41 composites for production of liquid biofuels. J. Fuel Chem. Technol. 45(7), 805816 (2017). https://doi.org/10.1016/S18725813(17)30039-7

21. Kusumastuti, H., Trisunaryanti, W., Falah, I.I., Marsuki, M.F.: Synthesis or mesoporous silica-alumina from lapindo mud as a support of $\mathrm{Ni}$ and Mo metals 
catalysts for hydrocracking of pyrolyzed $\alpha$ cellulose. Rassayan J. Chem. 11(2), 522-530 (2018).

https://doi.org/10.7324/RJC.2018.1122061

22. Luts, T., Suprun, W., Hofmann, D., Klepel, O., Papp, H.: Epoxidation of olefins catalyzed by novel $\mathrm{Mn}(\mathrm{III})$ and $\mathrm{Mo}(\mathrm{IV})$ Salen complexes immobilized on mesoporous silica gel Part I. Synthesis and characterization of homogeneous and immobilized $\mathrm{Mn}(\mathrm{III})$ and Mo(IV) Salen complexes. J. Mol. Catal. A Chem. 261, 1623

https://doi.org/10.1016/j.molcata.2006.07.0 35

23. Ghorbani, F., Younesi, H., Mehraban, Z., Çelik, M.S., Ghoreyshi, A.A., Anbia, M.: Preparation and characterization of highly pure silica from sedge as agricultural waste and its utilization in synthesis of mesoporous silica MCM-41. J. Taiwan Inst.

Chem. Eng. 44, 821-828 (2013). https://doi.org/10.1016/j.jtice.2013.01.019

24. Bai, K., Hao, J., Yang, Y., Qian, A.: The eefect of hydrotermal temperature on the properties of SBA-15 materials. Heliyon 6, e04436 https://doi.org/10.1016/j.heliyon.2020.e044 36

25. Akbari, A., Omidkhah, M., Darian, J.T.: Investigation of process variables and intesification effects of ultrasound applied in oxidative desulfurization of model diesel over $\mathrm{MoO}_{3} / \mathrm{Al}_{2} \mathrm{O}_{3}$ catalyst. Ultrason. Sonochem. 21, 692-705 (2014). https://doi,org/10.1016/j.ultsonch.2013.10. 004

26. Méndez, F.J., Franco-López, O.E., Díaz, G., Gómez-Cortés, A., Bokhimi, X., Klimova, T.E.: On the role of niobium in nanostructured Mo/Nb-MCM-41 and $\mathrm{NiMo} / \mathrm{Nb}-\mathrm{MCM}-41$ catalysts for hydrodesulfurization of dibenzthiophene. Fuel 280, $118550 \quad$ (2020). https://doi.org/10.1016/j.fuel.2020.118550

27. He, K., Chen, N., Wang, C., Wei, L., Chen $\mathrm{J} .:$ Method for determining crystal grain size by X-ray diffraction. Cryst.Res.Tecnol. 1700157, $1-6$ (2018). https://doi.org/10/1002/crat.201700157

28. Peng, H., Min, L., Qiu-lian, C.: $\mathrm{MoO}_{3} / \mathrm{Al}-$ SBA-15 modified catalyst and its application in coal tar hydrocracking. J. Fuel Chem. Technol. 48(9), 1079-1086. https://doi.org/10.1016/S1872-

5813(20)30072-4

29. Khojastehnezhad, A., Moeinpour, F., Vafaei, M.: Molybdenum oxide support on silica $\left(\mathrm{MoO}_{3} / \mathrm{SiO}_{2}\right)$ : An efficient and reusable catalyst for the synthesis of 1,8 dioxodecahydroacrdines under solvent free conditions. J.Mex.Chem.Soc. 59(1), 29-35 (2015). https://doi.org/10.29356/jmcs.v59i 1.11

30. Dhar, G.M., Kumaran, G.M., Kumar, M., Rawat, K.S., Sharma, L.D., Raju, B.D., Rao, K.S.R.: Physico-chemical characterization and catalysis on SBA-15 supported molybdenum hydrotrating catalyst. Catal. Today 99, 309-314 (2005). https://doi.org/10.1016/j.cattod.2004.10.00 5

31. Zhao, X., Wei, L., Cheng, S., Kadis, E., Cao, Y., Boakye, E., Gu, Z., Julson, J.: Hydroprocessing of carinata oil for hydrocarbon biofuel over $\mathrm{Mo}-\mathrm{Zn} / \mathrm{Al}_{2} \mathrm{O}_{3}$. Applied Catal. B, Environ. 196, 41-49 (2016). https://doi.org/10.1016/j.apcatb.2016.05.02 0 
32. Jeong, H., Shin, M., Jeong, B., Jang, J.H., Han, G.B., Suh, Y.: Comparison of activity and stability of supported $\mathrm{Ni}_{2} \mathrm{P}$ and $\mathrm{Pt}$ catalysts in the hydroprocessing palm oil into normal paraffins. J. Ind. Eng. Chem. 83 ,

$$
\text { 189-199 }
$$

https://doi.org/10.1016/j.jiec.2019.11.027

33. Phimsen, S., Kiatkittipong, W., Yamada, H., Tagawa, T., Kiatkittipong, K., Laosiripojana, N., Assabumrungrat, S.: Oil extracted from spent cofee grounds for biohydrotreated diesel production. Energy Convers. Manage 125 (2016). https://doi.org/10.1016/j.encoman.2016.08. 085

34. Han-u-domlarpyos, V., Kuchonthara, P., Reubroycharoen, P., Hinchiranan, N.: Quality improvement of oil palm shellderived pyrolisis oil via catalytic deoxygenation over $\mathrm{NiMoS} / \gamma-\mathrm{Al}_{2} \mathrm{O}_{3}$. Fuel 143 ,

$$
\text { 512-518 }
$$

https://doi.org/10.1016/j.fuel.2014.11/068

35. Barbera, E., Naurzaliyev, R., Asiedu, A., Bertucco, A., Resurreccion, E.P., Kumar, S.: Techno-economic analysis and life-cycle assessment of jet fuels production from waste cooking oil via in situ catalytic transfer hydrogenation. Renew. Energ. 160, 428-449 https://doi.org/10.1016/j.renene.2020.06.07 7

36. Burimsitthigul, T., Yoosuk, B., Ngamcharussrivichai, C., Prasassarakich, P.: Hydrocarbon biofuel from hydrotrating of palm oil over unsupported Ni-Mo sulfide catalysts. Renew. Energ. 163, 1648-1659 (2021). https://doi.org/10.1016/j.renene.2020.10.04 4

37. Pongsendana, M., Trisunaryanti, W.,
Artanti, F.W., Falah, I.I., Sutarno: Hydrocracking waste lubricant into gasoline over CoMo catalyst supported on mesoporous carbon from bovine bone gelatin. Korean J. Chem 34, 2591-2596 (2017). https://doi.org/10.1007/s11814017-0165-3

38. Ahmadi, S., Yuan, Z., Rohani, S., Xu, C.: Effects of nano-structured CoMo catalysts on hydrodeoxygenation of fast pyrolisis oil in dupercritical ethanol. Catal. Today 269, 182-194 https://doi.org/10.1016/j.cattod.2015.08.04 0

39. Taufiqurrahmi, N., Mohamed, A.R., Bhatia, S.: Deactivation and coke combustion studies of nanocrystalline zeolite beta in catalytic cracking of used palm oil. Chem. Eng. J. 163, 413-421 (2010). https://doi.org/10.1016/j.cej.2010.07.049

40. Rodríguez, E., Elordi, G., Valecillos, J., Izaddoust, S., Bilbao, J., Arandes, J.M., Castano, P.: Coke deposition and product distribution in the co-cracking of waste polyolefin derived streams and vacuum gas oil under FCC unit conditions. Fuel Process. Technol. 192, 130-139, (2019). http://doi.org/10.1016/j.fuproc.2019.04.012

41. Zhang, X., Chen, Q., Zhang, Q., Wang, C., Ma, L., Xu, Y.: Conversion of pyrolytic lignin to aromatic hydrocarbons by hydrocracking over pristine $\mathrm{MoO}_{3}$ catalyst. J. Anal. Appl. Pyro. 135, 60-66 (2018). https://doi.org/10.1016/j.jaap.2018.09.020 